\title{
Laboratorial atopy markers in children with human immunodeficiency virus
}

\author{
Cristina Rodrigues $\mathrm{Cruz}^{1} /{ }^{+}$, Vania Oliveira Carvalho², Rosaly Vieira Santos ${ }^{3}$, \\ Tony Tannous Tahan', Andrea Maciel Oliveira Rossoni ${ }^{1}$, Hermenio Cavalcante Lima ${ }^{3}$
}

${ }^{1}$ Divisão de Doenças Infecciosas Pediátricas ${ }^{2}$ Divisão de Dermatologia Pediátrica, Departamento de Pediatria ${ }^{3}$ Divisão de Imunologia Clínica e Alergia, Departamento de Patologia Médica, Universidade Federal do Paraná, Curitiba, PR, Brasil

Changes in immune system functions are one of the most important consequences of human immunodeficiency virus (HIV) infection. Studies have reported a higher prevalence of disease mediated by immunological hypersensitivity mechanisms in HIV-positive patients. This study aims to observe how immunological changes in HIV-infected children interfere in atopy determinants. Fifty-seven HIV-positive children were studied between June 2004-August 2005 to evaluate the possible modifications in atopy diagnosis from prick test environmental allergen reactivity. Patients were subjected to two evaluations: on both occasions, atopic and non-atopic groups were correlated with immunological $\left(C D 4^{+}\right.$and $C D 8^{+}$lymphocyte concentrations and serum levels of $\operatorname{Ig} A, \operatorname{IgM}, \operatorname{IgG}$ and $\operatorname{IgE}$ ) and viral parameters (HIV viral load). The percent atopy was 20.05 in the first and 29.82 in the second evaluation and atopy was diagnosed in patients without immunosuppression or with moderate immunosuppression. Six patients changed from a negative to a positive atopy profile. One patient with a decreased $C D 4^{+} T$ lymphocyte concentration failed to demonstrate prick test positivity between evaluations. Multivariate analysis showed that the variables associated with atopy diagnosis included a personal history of allergic diseases as well as elevated IgE for age and elevated IgE levels. Atopy development in HIV-infected children seems to be modulated by genetic and environmental factors as well as immunological condition.

Key words: HIV - child - immunoglobulin E - allergy

Beginning in the 1980s, with the first descriptions of AIDS and the later identification of the human immunodeficiency virus (HIV) as the causal agent, knowledge of immunological alterations that occur in the disease's evolution has been improving constantly.

HIV-infected patients present complex immunological alterations due to $\mathrm{CD} 4^{+} \mathrm{T}$ lymphocyte depletion and changes in the function of different immune effectors cells, such as polyclonal B cell activation and the consequent increase in immunoglobulin production (Rosenberg \& Fauci 1988). These immunological alterations are represented clinically by recurring bacterial infections, opportunistic infections and neoplasias (Luzuriaga \& Sullivan 2000, Starr 2003).

However, other factors have been identified in the disease's physiopathology such as an imbalance in cytokine immunoregulation, characterized by a reduction in Type 1 and an increase in Type 2 cytokines (Romagnani \& Maggi 1994, Clerici et al. 1997).

Different studies have suggested a possible increase in the prevalence of allergic diseases, such as IgE-mediated Type 1 hypersensitivity, in these patients who, paradoxically, have been evolving toward immunosuppression (Lin \& Lazarus 1995, Corominas et al. 2000). Recently, this contradictory effect has been attributed to functional

\footnotetext{
+Corresponding author: criscruz@ufpr.br

Received 10 September 2009

Accepted 12 March 2010
}

and quantitative alterations in regulatory $\mathrm{T}$ cells (Kinter et al. 2004, Eggena et al. 2005). These observations suggest that immunological alterations secondary to HIV infection alter the normal allergy control mechanisms, thus permitting an increase in the clinical expression of allergic diseases (Bacot et al. 1997).

However, the epidemiology and clinical and laboratory manifestations of atopy have been monitored preferentially in transverse studies in the adult infected population (Sample et al. 1990, Small et al. 1993, Corominas et al. 2000). This study was developed to evaluate prospectively whether immunological alterations and their evolution during the course of HIV infection in children influence the development and prevalence of atopic diseases.

\section{PATIENTS, MATERIALS AND METHODS}

Study design - This was a longitudinal, prospective and descriptive study performed between June 2004August 2005 involving children with confirmed HIV infection followed in outpatient clinics at a tertiary reference hospital. HIV infection was defined according to Centers for Disease Control and Prevention (CDC 1994). Children between 1-13 years old were included randomly. This group was followed regularly in the ambulatory care clinic and their parents or legal guardians had consented. Exclusion criteria were applied for those children who used drugs that could interfere in laboratory exam results, such as corticosteroids, anti-histamines and hyperimmune gamaglobulin.

A total of 68 patients was initially included in the study. All underwent clinical evaluation, complementary laboratory exams and the prick test. Demographic and medi- 
cal history data were collected from medical records with emphasis on personal history suggestive of allergic diseases. Patients were evaluated twice between 6-12 months, with a mean of 10 months. Of the original 68 patients participating in the first evaluation, 57 were selected for the second. Eleven patients did not undergo the second evaluation; the reasons for this were that 10 did not attend the routine consultation on the planned date or did not provide samples for the laboratory exams. In the other case, the second prick test was not authorized by the parents.

Laboratory exams - The following laboratory exams were performed at both evaluations: $\mathrm{CD} 4^{+}$and $\mathrm{CD} 8^{+}$ $\mathrm{T}$ lymphocyte concentrations $(\mu \mathrm{L})$ by flow cytometry, HIV viral load (number of viral copies) by RT-PCR, serum levels of IgA, IgM and IgG by nephelometry, serum levels of immunoglobulin $\mathrm{E}$ by radioimmunoassay and complete hemogram. IgE, IgG, IgM and IgA levels were evaluated using reference tables related to age group (Adelman et al. 2002, Adkinson et al. 2003).

Patient immunodeficiency levels were based upon $\mathrm{CD}^{+} \mathrm{T}$ lymphocyte counts from each evaluation using the immunological classification table adopted by the CDC (1994).

Prick tests were performed with environmental allergens (domestic dust, grasses, mites, fungi, cat hair and cockroaches), $10 \mathrm{mg} / \mathrm{mL}$ histamine as a positive control and $0.9 \%$ saline solution as a negative control. All extracts and positive controls were obtained from IPI ASAC BRASIL ${ }^{\circledR}$. Patients were advised not to use anti-histamines for seven days prior to the prick test.

The prick test was considered positive when the presence of papules with a mean orthogonal diameter of $\geq 3$ $\mathrm{mm}$ was observed. Patients were then classified as either atopic (patients with a positive prick test to one or more of the tested allergens) or non-atopic (patients displaying negative results to all extracts).

Statistical analysis - The data were analyzed using JMP 5.1 ${ }^{\circledR}$ statistics software. The Student's $t$ test and the Mann-Whitney, Wilcoxon and Kruskal-Wallis non-parametric tests were used to compare continuous variables between groups. The chi-squared and Fisher exact tests were used for two or more nominal variables. Logistic regression with the stepwise forward procedure was performed to identify variables associated with a diagnosis of atopy and included factors such as personal history of allergic disease, $\mathrm{CD} 4^{+}$and $\mathrm{CD} 8^{+} \mathrm{T}$ lymphocyte counts, viral load, IgE, IgG, IgM and IgA levels, their classification as normal or elevated for age group and absolute count and percentage of eosinophils. The minimum significance level was set at 5\%.

Ethics - This study was approved by our institution's Human Research Ethical Committee.

\section{RESULTS}

The average ages varied between 1.30-13.34 years with a mean of $7.36 \pm 3.33$ years from the initial sample. Females predominated $(63.16 \%$; 36 patients). The median time from HIV infection diagnosis was 4.27 years, varying from $0.49-11.32$ years. All patients acquired HIV infection by vertical transmission.
Median serum immunoglobulin values were 91.20 $\mathrm{UI} / \mathrm{mL}$ for IgE, $1640 \mathrm{mg} / \mathrm{dL}$ for $\mathrm{IgG}, 134.50 \mathrm{mg} / \mathrm{dL}$ for IgM and $178 \mathrm{mg} / \mathrm{dL}$ for IgA. According to age reference tables, concentrations of IgE, IgG, IgM and IgA were elevated in 24 (42.10\%), 17 (30.35\%), 37 (66.07\%) and 20 (35.71\%) patients, respectively.

Prick test results at first evaluation showed 12 (21.05\%) patients as being atopic. Of those 12 children, seven reacted to only one extract, two to two extracts, one to three extracts, one to four extracts and one to five of the six allergen extracts tested. Immediate hypersensitivity was mainly to mite and domestic dust extracts.

Comparing atopic and non-atopic group patients, personal histories of allergic diseases showed that six (50\%) of the 12 atopic group children had reported at least one atopic symptom of some kind. In the non-atopic group, 42 (93.33\%) denied having clinical symptoms $(\mathrm{p}=0.0015)$.

Atopic patients had a median IgE of $237.5 \mathrm{UI} / \mathrm{mL}$, which was higher than non-atopic patients $(78.2 \mathrm{UI} / \mathrm{mL}$, $\mathrm{p}=0.0328)$. Medians of $\operatorname{Ig} \mathrm{A}$, IgM and $\operatorname{IgG}$ were similar between groups (Table I).

Comparing the two groups for elevated immunoglobulin levels for their age group, we observed that $75 \%$ of atopic patients and $33.33 \%$ of non-atopic patients were considered to have elevated levels $(\mathrm{p}=0.0187)$. The proportion of patients with elevated IgG, IgM and IgA levels were similar between groups.

Absolute count and percentages of eosinophils were similar between groups, with a median of 138.30 cells/ $\mu \mathrm{L}$ and $1.5 \%$ for atopic as compared with 204 cells/ $\mu \mathrm{L}$ and $3 \%$ for non-atopic patients $(\mathrm{p}=0.4448$ and $\mathrm{p}$ $=0.4470$, respectively) (Table I). There was no difference between groups for $\mathrm{CD}^{+}$and $\mathrm{CD} 8^{+} \mathrm{T}$ lymphocyte counts and viral load (Table I).

Regarding $\mathrm{CD}^{+}{ }^{+} \mathrm{T}$ lymphocyte counts from the first evaluation, 10 of the $12 \mathrm{HIV}$-positive atopic patients did not have immunosuppression and two patients had moderate immunosuppression (Figure).

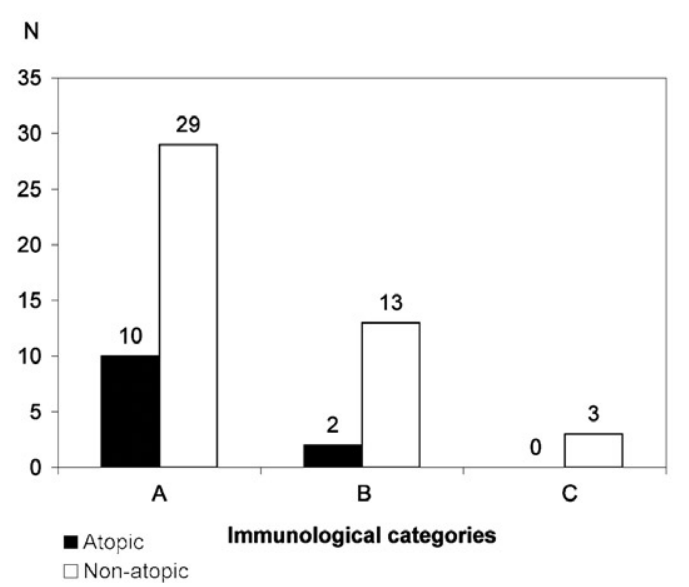

Immunological classification of atopic and non-atopic groups according to $\mathrm{CD} 4^{+} \mathrm{T}$ lymphocyte count at first evaluation. $\mathrm{n}=57 ; \mathrm{p}=0.2883$; A: absence of immunossupression; B: moderate immunossupression; $\mathrm{C}$ : strong immunossupression. 
TABLE I

Comparison between atopic and non-atopic groups for $\operatorname{IgE}, \operatorname{IgG}, \operatorname{IgM}$ and $\operatorname{IgA}$ levels, $\mathrm{CD}^{+}, \mathrm{CD}^{+} \mathrm{T}$ lymphocyte counts and viral load at first and second evaluations

\begin{tabular}{|c|c|c|c|c|c|c|}
\hline \multirow[b]{2}{*}{ Count (median) } & \multicolumn{3}{|c|}{ First evaluation } & \multicolumn{3}{|c|}{ Second evaluation } \\
\hline & Atopic & Non-atopic & $\mathrm{p}$ value & Atopic & Non-atopic & $\mathrm{p}$ value \\
\hline $\operatorname{IgE}(\mathrm{UI} / \mathrm{mL})$ & 237.50 & 78.20 & 0.0328 & 410 & 59.05 & 0.0002 \\
\hline $\operatorname{IgG}(\mathrm{mg} / \mathrm{dL})$ & 1465 & 1660 & 0.3327 & 1775 & 1630 & 0.7953 \\
\hline $\operatorname{IgM}(\mathrm{mg} / \mathrm{dL})$ & 123.50 & 138.50 & 0.2550 & 124.50 & 130 & 0.5974 \\
\hline $\operatorname{IgA}(\mathrm{mg} / \mathrm{dL})$ & 191 & 173.50 & 0.8967 & 180.50 & 160 & 0.4418 \\
\hline Eosinophils (cell/ $\mu \mathrm{L}$ ) & 138.30 & 204 & 0.4448 & 517 & 215.40 & 0.0037 \\
\hline $\mathrm{CD}^{+}(\mathrm{cell} / \mu \mathrm{L})$ & 991 & 750 & 0.6526 & 870 & 801 & 0.2188 \\
\hline $\mathrm{CD}^{+}(\operatorname{cell} / \mu \mathrm{L})$ & 1063 & 1286 & 0.1128 & 1198 & 1280 & 0.7272 \\
\hline Viral load (copies/mL) & 1430 & 6340 & 0.1202 & 12000 & 23550 & 0.4732 \\
\hline Viral load (log) & 3.15 & 3.80 & 0.1202 & 4.07 & 4.36 & 0.4732 \\
\hline
\end{tabular}

Logistic regression analysis showed factors associated with atopic diagnosis at first evaluation. These factors were personal history of allergic diseases $(p=$ 0.0003 ) and proportion of patients considered to have elevated IgE levels for their age $(p=0.0111)$.

In the second phase of the study, the prick test showed a change in atopy profile. Seventeen (29.82\%) of the 57 children were diagnosed as atopic. From the 45 non-atopic patients from the first evaluation, six had at least one positive prick test and were considered atopic in the second assessment. Of the 12 atopic patients identified at the first evaluation, one presented a negative prick test at the second evaluation, having therefore become non-atopic.

In the group of six patients whose prick test profile changed from negative to positive, at the first examination the mean age was 7.41 years, $\mathrm{SD}=2.58$ years varying between 4.4-11.06 years. In the second evaluation, the average was 8.15 years with a SD of 2.7, varying between 5.2-12 years.

$\mathrm{CD}^{+}$and $\mathrm{CD}^{+} \mathrm{T}$ lymphocyte levels and viral load were similar in both groups at the second evaluation. Atopic patients had higher IgE levels than non-atopic ( $\mathrm{p}$ $=0.002$ ) patients, as well as proportion of patients with elevated $\operatorname{IgE}$ for their age $(\mathrm{p}<0.001)$. In contrast with the first evaluation, the second revealed a higher percentage and absolute eosinophil counts in atopic (medians of $5.50 \%$ and 517 cells $/ \mu \mathrm{L}$ ) than in non-atopic patients (medians of $3 \%$ and 215.40 cells $/ \mu \mathrm{L}$ ). The atopic group and the non-atopic group showed a significance of $p=$ 0.0278 and $p=0.0037$, respectively (Table I).

Factors associated with a diagnosis of atopy in the second evaluation by logistic regression analysis included a personal history of allergic diseases $(\mathrm{p}=0.0034)$, IgE serum levels $(p=0.0436)$ and the proportion of patients with elevated $\operatorname{IgE}$ for their age $(\mathrm{p}=0.0085)$.

Table II shows the evolution of 18 patients with a positive prick test in some phase of the study. Factors such as CDC immunological classification according to $\mathrm{CD} 4^{+}$ $\mathrm{T}$ lymphocyte counts, IgE levels and eosinophil levels were found at both phases.
Seventeen patients maintained their immunological status in the second evaluation. Only one patient, who showed worsening immune responses from the first-second evaluation in accordance with the CDC classification, changed the profile from atopic to non-atopic. Six patients whose prick tests changed from negative to positive between evaluations had no immunological alterations (Table II). Any changes that were seen were observable in the specificity response to cutaneous extracts between the analysis phases. The unique exception was the number of patients that recognized the extracts. The mean orthogonal papule diameter was different in patients who were negative at evaluation one and positive at evaluation two for mite mix and domestic dust extracts $(p=0.049$ and $\mathrm{p}=0.006$, respectively).

At first evaluation, the six patients had higher mean IgE levels than the patients with negative prick tests, with measure results of $322 \mathrm{UI} / \mathrm{mL}$ and $69 \mathrm{UI} / \mathrm{mL}$, respectively $(\mathrm{p}=0.0886)$.

\section{DISCUSSION}

Studies using different methodologies suggest a higher prevalence of atopy in HIV-infected patients. However, most of these studies are focused on adults with only one diagnostic test and a single evaluation. Some have considered personal history of allergic diseases as a diagnosis (Wright et al. 1990, Ellaurie et al. 1995, Lin \& Lazarus 1995, Secord et al. 1996), whereas others have used laboratory techniques, such as the prick test, or studied specific IgE for environmental allergens (Nissen et al. 1999, Corominas et al. 2000). This study was based on a group of infected children using environmental allergen prick test results as the criterion for defining the presence or absence of atopy. We demonstrated that allergic reaction against these environmental allergens could change. Prospective analysis of the results suggests that immune alterations due to the evolution of HIV infection in children interfere with the development and prevalence of atopic diseases.

The frequency of a positive prick test in the study population was $21 \%$ at the first evaluation and $30 \%$ at 
TABLE II

Laboratory characteristics of the 18 patients presenting at least one positive Prick test (atopic) at some time in the study

\begin{tabular}{|c|c|c|c|c|c|c|c|c|c|c|}
\hline \multirow[b]{2}{*}{ Patient code } & \multicolumn{2}{|c|}{ Atopic } & \multicolumn{2}{|c|}{ Immunossupression grade } & \multicolumn{2}{|c|}{$\operatorname{IgE}$} & \multicolumn{2}{|c|}{ IgE for age group } & \multicolumn{2}{|c|}{ Eosinophils (\%) } \\
\hline & $1 \mathrm{st}$ & 2 nd & $1 \mathrm{st}$ & 2nd & $1 \mathrm{st}$ & $2 \mathrm{nd}$ & $1 \mathrm{st}$ & 2 nd & $1 \mathrm{st}$ & 2nd \\
\hline 3 & + & + & 1 & 1 & $>2000$ & 1786 & $\mathrm{E}$ & $\mathrm{E}$ & 0 & 15 \\
\hline 12 & - & + & 1 & 1 & $>2000$ & $>2000$ & $\mathrm{E}$ & $\mathrm{E}$ & 3 & 2 \\
\hline 16 & + & + & 1 & 1 & 1173 & 1234 & $\mathrm{E}$ & $\mathrm{E}$ & 9 & - \\
\hline 17 & - & + & 1 & 1 & 25,6 & 14,4 & $\mathrm{~N}$ & $\mathrm{~N}$ & 1 & 2 \\
\hline 19 & + & + & 1 & 1 & 162 & 310 & $\mathrm{E}$ & $\mathrm{E}$ & 3 & 14 \\
\hline 20 & + & + & 1 & 1 & 215 & 822 & $\mathrm{E}$ & $\mathrm{E}$ & 5 & 5 \\
\hline 22 & + & + & 1 & 1 & 27 & 110 & $\mathrm{~N}$ & $\mathrm{E}$ & 1 & 5 \\
\hline 27 & - & + & 1 & 1 & 535 & 254 & $\mathrm{E}$ & $\mathrm{E}$ & 7 & 7 \\
\hline 29 & + & + & 2 & 2 & 466 & 334 & $\mathrm{E}$ & $\mathrm{E}$ & 0 & 4 \\
\hline 31 & - & + & 1 & 1 & 89 & 410 & $\mathrm{~N}$ & $\mathrm{E}$ & 2 & 4 \\
\hline 37 & + & + & 1 & 1 & 1007 & 991 & $\mathrm{E}$ & $\mathrm{E}$ & 1 & 8 \\
\hline 38 & + & + & 1 & 1 & 260 & 220 & $\mathrm{E}$ & $\mathrm{E}$ & 1 & 2 \\
\hline 58 & + & + & 1 & 1 & $>2000$ & 1240 & $\mathrm{E}$ & $\mathrm{E}$ & 20 & 6 \\
\hline 59 & + & + & 1 & 1 & 156 & 468 & $\mathrm{E}$ & $\mathrm{E}$ & 6 & 4 \\
\hline 62 & + & + & 2 & 2 & 141 & 84 & $\mathrm{~N}$ & $\mathrm{~N}$ & 2 & 6 \\
\hline 64 & - & + & 1 & 1 & 1497 & $>2000$ & $\mathrm{E}$ & $\mathrm{E}$ & 11 & 6 \\
\hline 67 & + & - & 1 & 2 & 2 & 11 & $\mathrm{~N}$ & $\mathrm{~N}$ & 1 & 4 \\
\hline 68 & - & + & 2 & 2 & 109 & 89 & $\mathrm{E}$ & $\mathrm{N}$ & 7 & 10 \\
\hline
\end{tabular}

E: elevated; IgE values expressed in UI/ml; N: normal; 1: absence of immunossupression; 2: moderate immunossupression; 3: strong immunossupression.

the second. This was higher than those rates observed by Corominas et al. (2000) in infected adults (18\%) and similar to children (28\%) (Bacot et al. 1997).

The results suggest that there are special characteristics in this population that correlate with the development of this type of hypersensitivity and immunological reconstitution. The majority of the atopic patients in this study had normal $\mathrm{CD}^{+} \mathrm{T}$ values for their age. Carvalho et al. (2008) showed an association between Type 1 hypersensitivity-mediated dermatitis in HIV-positive children with improved immune responses. Lin and Lazarus (1995) correlated asthma in HIV-positive adults with lower level immunosuppression. A higher prevalence of atopy was observed in patients with increased $\mathrm{CD}^{+}$ $\mathrm{T}$ lymphocyte levels in relation to those with advanced disease (Corominas et al. 2000). In the same way, a separate study (Goetz et al. 1997) reported that aeroallergenspecific IgE was less prevalent with disease in progress.

Most patients whose prick test response changed to negative from positive presented $\mathrm{CD}^{+}$levels compatible with immunocompetence and they maintained these levels in both evaluations. The opposite result occurred in one patient with worsening immune responses. This patient had a $\mathrm{CD}^{+} \mathrm{T}$ cell reduction and became negative at the second prick test. These findings suggest that the $\mathrm{CD}^{+}$level influences skin test results. As suggested by Corominas et al. (2000), these immunological changes that can occur in the early stages of HIV infection or during im- mune reconstruction could induce an increased prevalence to allergic diseases in patients genetically predisposed to develop atopy. However, laboratory and clinical expression could decrease along with disease progression once their immunological capacity is available to respond to allergens and trigger an allergic reaction - an effect that is lost in the high immunosuppression phases.

Recent reports have suggested that the immune changes in HIV-infected individuals could be linked to alterations in $\mathrm{T}$ lymphocyte regulators, known as Tregs $\left(\mathrm{CD}^{+} \mathrm{CD} 25^{+} \mathrm{FoxP}^{+}\right)$. In the initial phase, higher Treg activity induces a paradoxical effect of stabilized $\mathrm{CD}^{+}$levels by reducing $\mathrm{CD}^{+} \mathrm{T}$ activity (Kinter et al. 2004, Eggena et al. 2005). Therefore, the progressive reduction in Tregs results in an increased $\mathrm{Th} 2 \mathrm{CD}^{+} \mathrm{T}$ lymphocyte response to environmental allergens. This leads to an increased prevalence of atopy that decreases when immunosuppression develops (Xystrakis et al. 2006). However, during immunological reconstruction, $\mathrm{CD}^{+} \mathrm{T}$ lymphocyte levels gradually increase and there is a possible slower recuperation of $\mathrm{T}$ lymphocyte regulators. As a result, the atopic response returns.

In non-infected individuals, Th2 lymphocyte clones that react with environmental antigens are activated constantly due to permanent exposure (Roberts et al. 2005). In the HIV-infected patient, this sensitivity seems to disappear with disease progress (Goetz et al. 1997), presumably due to the destruction of memory clones that occurs with 
the progressive loss of $\mathrm{CD}^{+} \mathrm{T}$ lymphocytes. This is the same phenomenon that occurs in the case of lost responses to antigen-based vaccines (Douek et al. 2000, Feeney et al. 2003, De Milito et al. 2004, Rosenblatt et al. 2005). Since immunoglobulin production is T lymphocyte-dependent, a reduction in $\mathrm{Th} 2 \mathrm{CD}^{+}$lymphocyte clones decreases $\mathrm{B}$ lymphocyte stimulation, thus resulting in reduced $\operatorname{IgE}$ levels. As IgE half-life in tissue is at a maximum at 14 days (Hamilton 2001), there is a progressive disappearance of the prick test response in these patients.

Immune restoration after introducing anti-retroviral therapy allows new cell clones to appear from the thymus (Douek et al. 2000, Johnston et al. 2001, Resino et al. 2003, Touloumi et al. 2004, Ye et al. 2004). These new cells could be stimulated quickly by environmental allergens, resulting in the production of IL-4-type inductor cytokines and IgE by allergen-specific B lymphocytes. When this happens, prick positivity can be re-established in the genetically predisposed individuals.

Upon analyzing the six patients whose prick test profile changed from negative to positive, the results demonstrate that nearly all variables were similar in patients who were atopic at both evaluation times and they were different in non-atopic patients. In these six patients, we could not detect laboratorial alterations common to atopy at this point. However, fully clinical development occurred at the immune restoration phase, which was quantitatively and functionally associated with a Th2 clone expression improvement.

This study shows an elevated prevalence of atopy in HIV-infected children and demonstrates a change in the atopic sensitivity profile in this population. The data suggest that the development of atopy in HIV-infected children is modulated by genetic and environmental factors as well as immunological condition. The lost of follow-up of $16 \%$ of the initial sample represented a limitation of the study. Therefore, we believe that studies with larger populations and longer follow-up may corroborate our findings in this present paper.

\section{REFERENCES}

Adelman DC, Casale TB, Corren J 2002. Manual of allergy and immunology, Williams \& Wilkins, Lippincott, $544 \mathrm{pp}$.

Adkinson NF, Yunginger JW, Busse WW, Bochner BS, Holgate SH, Simons FER 2003. Middleton's allergy: principles and practice, 6th ed., Mosby, Philadelphia, $1841 \mathrm{pp}$.

Bacot BK, Paul ME, Navarro M, Abramson SL, Kline MW, Hanson IC, Rosenblatt HM, Shearer WT 1997. Objective measures of allergic disease in children with human immunodeficiency virus infection. J Allergy Clin Immunol 100: 707-711.

Carvalho VO, Cruz CR, Marinoni LP, Lima HC 2008. Infectious and inflammatory skin diseases in children with HIV infection and their relation with the immune status - evaluation of 127 patients. Ped Dermatol 25: 571-573.

CDC - Centers for Diseases Control and Prevention 1994. Revised classification system for human immunodeficiency virus infection in children less than 13 years of age. MMWR 43: 1-19.

Clerici M, Fusi ML, Ruzzante S, Piconi S, Biasin M, Arienti D, Trabattoni D, Villa ML 1997. Type 1 and type 2 cytokines in HIV infection - a possible role in apoptosis and disease progression. Ann Med 29: 185-188.
Corominas M, Garcia JF, Mestre M, Fernandez-Viladrich P, Buendia E 2000. Predictors of atopy in HIV-infected patients. Ann Allergy Asthma Immunol 84: 607-611.

De Milito A, Nilsson A, Titanji K, Thorstensson R, Reizenstein E, Narita M, Grutzmeier S, Sönnerborg A, Chiodi F 2004. Mechanisms of hypergammaglobulinemia and impaired antigen-specific humoral immunity in HIV-1 infection. Blood 103: 2180-2186.

Douek DC, Koup RA, McFarland RD, Sullivan JL, Luzuriaga K 2000. Effect of HIV on thymic function before and after antiretroviral therapy in children. J Infect Dis 181: 1479-1482.

Eggena MP, Barugahare B, Jones N, Okello M, Mutalya S, Kityo C, Mugyenyi P, Cao H 2005. Depletion of regulatory T cells in HIV infection is associated with immune activation. J Immunol 174: 4407-4414.

Ellaurie M, Rubinstein A, Rosenstreich DL 1995. IgE levels in pediatric HIV-1 infection. Ann Allergy Asthma Immunol 75: 332-336.

Feeney ME, Draenert R, Roosevelt KA, Pelton SI, McIntosh K, Burchett SK, Walker BD, Goulder PJ 2003. Reconstitution of virus-specific CD4 proliferative responses in pediatric HIV-1 infection. J Immunol 171: 6968-6975.

Goetz DW, Webb EL, Whisman BA, Freeman TM 1997. Aeroallergen-specific IgE changes in individuals with rapid human immunodeficiency virus disease progression. Ann Allergy Asthma Immunol 78: 301-306.

Hamilton M 2001. Immunology and pathophysiology of allergic disease. In S Naguwa, M Gershwin, Allergy and immunology secrets, 1st ed., Elsevier, Philadelphia, p. 13-31.

Johnston AM, Valentine ME, Ottinger J, Baydo R, Gryszowka V, Vavro C, Weinhold K, St Clair M, McKinney RE 2001. Immune reconstitution in human immunodeficiency virus-infected children receiving highly active antiretroviral therapy: a cohort study. Pediatr Infect Dis J 20: 941-946.

Kinter AL, Hennessey M, Bell A, Kern S, Lin Y, Daucher M, Planta M, McGlaughlin M, Jackson R, Ziegler SF, Fauci AS 2004. CD25( $\left(^{+}\right)$ $\mathrm{CD}\left(^{+}\right)$regulatory $\mathrm{T}$ cells from the peripheral blood of asymptomatic HIV-infected individuals regulate $\mathrm{CD} 4\left(^{+}\right)$and $\mathrm{CD} 8\left(^{+}\right)$ HIV-specific $\mathrm{T}$ cell immune responses in vitro and are associated with favorable clinical markers of disease status. $J$ Exp Med 200: 331-343.

Lin RY, Lazarus TS 1995. Asthma and related atopic disorders in outpatients attending an urban HIV clinic. Ann Allergy Asthma Immunol 74: 510-515.

Luzuriaga K, Sullivan JL 2000. Viral and immunopathogenesis of vertical HIV-1 infection. Pediatr Clin North Am 47: 65-78.

Nissen D, Nolte H, Permin H, Heinig J, Skov PS, Norn S 1999. Evaluation of IgE-sensitization to fungi in HIV-positive patients with eczematous skin reactions. Ann Allergy Asthma Immunol 83: $153-159$.

Resino S, Sanchez-Ramon S, Correa R, Navarro ML, Bellon JM, Munoz-Fernandez MA 2003. Reconstitución clínica e inmunológica completa tras el tratamiento antirretroviral de gran actividad en un niño infectado verticalmente por el virus de la inmunodeficiencia humana tipo 1 con enfermedad avanzada. Med Clin (Barc) 29: 417-420.

Roberts G, Peckitt C, Northstone K, Strachan D, Lack G, Henderson J, Golding J, ALSPAC Study Team 2005. Relationship between aeroallergen and food allergen sensitization in childhood. Clin Exp Allergy 35: 933-940.

Romagnani S, Maggi E 1994. Th1 versus Th2 responses in AIDS. Curr Opin Immunol 6: 616-622.

Rosenberg ZF, Fauci AS 1988. Immunopathogenic mechanisms in human immunodeficiency virus (HIV) infections. Ann NY Acad Sci 546: 164-174. 
Rosenblatt HM, Stanley KE, Song LY, Johnson GM, Wiznia AA, Nachman SA, Krogstad PA 2005. Immunological response to highly active antiretroviral therapy in children with clinically stable HIV-1 infection. J Infect Dis 192: 445-455.

Sample S, Chernoff DN, Lenahan GA, Serwonska MH, Rangi S, Sherman JW, Sooy CD, Hollander H, Goetzl EJ 1990. Elevated serum concentrations of IgE antibodies to environmental antigens in HIV-seropositive male homosexuals. $J$ Allergy Clin Immunol 86: 876-880.

Secord EA, Kleiner GI, Auci DL, Smith-Norowitz T, Chice S, Finkielstein A, Nowakowski M, Fikrig S, Durkin HG 1996. IgE against HIV proteins in clinically healthy children with HIV disease. $J$ Allergy Clin Immunol 98: 979-984.

Small CB, Kaufman A, Armenaka M, Rosenstreich DL 1993. Sinusitis and atopy in human immunodeficiency virus infection. $J$ Infect Dis 167: 283-290.
Starr SE 2003. Immunopathogenesis of pediatric HIV infection. In WT Shearer, IC Hanson, Medical management of AIDS in children, Saunders, Philadelphia, p. 53-68.

Touloumi G, Pantazis N, Karafoulidou A, Mandalaki T, Goedert JJ, Kostrikis LG, Hatzakis A 2004. Changes in T cell receptor excision DNA circle (TREC) levels in HIV type 1-infected subjects pre- and post-highly active antiretroviral therapy. AIDS Res Hum Retroviruses 20: 47-54.

Wright DN, Nelson RP Jr, Ledford DK, Fernandez-Caldas E, Trudeau WL, Lockey RF 1990. Serum IgE and human immunodeficiency virus (HIV) infection. $J$ Allergy Clin Immunol 85: 445-452.

Xystrakis E, Boswell SE, Hawrylowicz CM 2006. T regulatory cells and the control of allergic disease. Expert Opin Biol Ther 6: 121-133.

Ye P, Kirschner DE, Kourtis AP 2004. The thymus during HIV disease: role in pathogenesis and in immune recovery. Curr HIV Res 2: $177-183$. 